\title{
DIGITALCOMMONS
}

@WAYNESTATE-

Criticism

Volume 62 | Issue 4

Article 8

2020

\section{The Immersive Installation as Feminist Intervention}

Christina Yglesias

christinayglesias@gmail.com

Follow this and additional works at: https://digitalcommons.wayne.edu/criticism

\section{Recommended Citation}

Yglesias, Christina (2020) "The Immersive Installation as Feminist Intervention," Criticism: Vol. 62 : Iss. 4 , Article 8.

Available at: https://digitalcommons.wayne.edu/criticism/vol62/iss4/8 
THE IMMERSIVE

INSTALLATION

AS FEMINIST

INTERVENTION

Christina Yglesias

A Capsule Aesthetic: Feminist

Materials in New Media Art by

Kate Mondloch. Minneapolis:

University of Minnesota Press, 2018. 168 pp. Paper $\$ 27.00$.
In A Capsule Aesthetic: Feminist Materials in New Media Art, Kate Mondloch situates the practices of three prominent contemporary artists, Pipilotti Rist, Patricia Piccinini, and Mariko Mori, within the emerging field of new materialisms. These three artists encompass a wide range of post-1990 new media art installation practices informed by feminism. While their works have been exhibited at important institutions and exhibitions such as the Museum of Modern Art and the Venice Biennale, critics and theorists have often overlooked and dismissed these artists' practices as unworthy of serious study. Installations such as Pour Your Body Out (2008) by Pipilotti Rist, We Are Family (2003) by Patricia Piccinini, and Wave UFO (1999-2003) by Mariko Mori achieved popular success, driving museumgoers to the institutions that housed them, but many reviewers criticized these works for relying on spectacle and lacking in criticality.

Mondloch offers a refreshing counternarrative, showing how these artists thoughtfully refigure spectatorship and viewership to explore complex themes of embodiment, relationships between the human and nonhuman, and interaction with technological interfaces. She asserts that "the experiential and environmental works of artists such as Rist, Piccinini, and Mori promote 
a critical and potentially revelatory spectatorship: one deeply informed by feminism's longheld epistemological commitment to exploring the mechanisms by which bodies and matters become meaningful" (6). The works by all three artists place us in environments and situations that make us aware of our own our bodies as material. Further, these immersive environments are not experienced alone but instead make us aware of the relationship between our own material bodies in relationship both to other viewers and to the technological interfaces of the works themselves, all in the context of a museum space.

Mondloch begins the book by offering an overview and introduction to the ideas set forth by several new materialist thinkers, such as Diana Coole, Samantha Frost, and Susan Heckman. She notes that these various theories "tend to share certain basic characteristics, namely, a critique of anthropocentrism, an emphasis on the self-organizing power of matter, a commitment to thinking from a planetary perspective, a reevaluation of subjectivity by accentuating the agency of nonhuman forces, and, ultimately, a reconsideration of the bases of contemporary ethics" (11). In this model, new materialism rejects the assumed superiority of human rationality and instead explores the relationships created between the material body and the social and psychological spheres it inhabits, especially as the human collides with nonhuman technologies and beings. In fact, women in patriarchal societies have never had the freedom to experience their existence and perception of selves apart from their gendered condition and gendered bodies, which in part explains the connection between feminist inquiry and new materialisms.

In Chapter 2, Mondloch investigates the legacy of feminist post-structuralist theory of the 1970s and 1980s from the context of post-1990 new media art. She again pushes back against oversimplified, prevailing views of feminist art and theory in order to "draw out the significant and underappreciated points of continuity between feminist theory and media art practice in the 1970s and 1980s and the present day" (21). She links the contemporary practices of Rist, Piccinini, and Mori to earlier post-structuralist feminist works and theories that have often been seen as separate and divergent. The text's first two chapters skillfully provide the framework and context necessary to deeply analyze key works of Rist, Piccinini, and Mori. With distinctive aesthetics and subject matter, their practices may initially appear to share little in common. In the following three chapters, Mondloch dives deep into each 
artist's practice while identifying commonalities and shared frameworks between them.

Chapter 3 focuses on the colorful, immersive video installations of the Swiss artist Pipilotti Rist. The discussion centers on Rist's 2008 video installation, Pour Your Body Out, at the Museum of Modern Art. The installation transformed the museum's massive atrium space, covering three walls with projections, complete with pink curtains, plush carpet, and breast-shaped projectors protruding from the walls. The colorful, dream-like video depicting female bodies and natural forms loops out of sync with an electronic soundtrack. Viewers may splay out on a custom eye-shaped sofa, lounge on the carpeted floor, mill about, or gaze down from the museum's upper floors. Mondloch asserts that Pour Your Body Out creates a self-reflexive experience of critical proximity that is "simultaneously reflexively critical and inexorably immersive" (63). A viewer becomes immersed, yet aware of this immersion. The cozy environment invites them to relax while, simultaneously, the imagery makes them hyperaware of their own bodies in space, especially in relation to other viewers' bodies. Therefore, the work creates a sense of embodiment and interconnectedness, all while the hyperfeminized space contrasts with the masculine modernity of the museum's history and architecture.

Chapter 4 delves into the curious bioart of the Australian multimedia artist Patricia Piccinini, focusing on the 2003 exhibition, $W e$ are Family, exhibited in the Australian pavilion at the Venice Biennale. Made up of several sculptures, installations, and one video, the show featured Piccinini's signature hyperreal transgenic life forms. The Young Family, a sculpture largely modeled from silicone and human hair, is one such example. The work resembles a hybrid pig/human mother breastfeeding a litter of young, inspiring both empathy and discomfort: "To encounter these works of art in their fullness is to come face-to-face with the inexhaustible, nonreciprocal otherness of nonhuman technological beings, and, crucially, to care for them all the same" (85). Piccinini's works force us to consider our own human bodies, the bodies of unknown life forms, and the current and future possibilities and ethical responsibility of genetic science and cloning.

Chapter 5 discusses the Japanese multimedia artist Mariko Mori, using Wave UFO (1999-2003) as a prime example of her engagement with the practices and ideas of neuroscience. First exhibited at the Kunsthaus Bregenz in Austria, Wave UFO is a sleek, podlike structure that welcomes three 
viewers at a time. Once inside, each viewer is fitted with brainwave monitoring EEG electrodes and cradled by a squishy technogel seat. The participants' brainwaves are visualized into a mesmerizing shapes and colors reminiscent of cellular processes and the cosmos. Eventually, the visualizations affect the brain activity, and each participant's brain waves begin to affect the other two participants' brain waves, forming a complex network of neurofeedback: "Mori's installation affirms that human cognition is always embodied and, moreover, that the sites of embodiment are dispersed across biological, social, and cultural registers." (88) Her work simultaneously uses the tools of neuroscience while subverting them, allowing us to look at our own brains as interconnected with our environment, our body, and the people around us.

Mondloch posits that the framework of new materialisms not only allows us to more deeply understand these works of art but also that these works of art can serve as methods of research for the field of new materialisms, forming a symbiotic relationship between theory and practice. She concludes the book by defining the term she lays out in its title, a capsule aesthetics. While Mariko Mori's work most is the most clearly associated with this idea, she argues that all three artists can be viewed through this lens: "These works of art invite us to experience not only our embodied absorption within, but also our ethical-political responsibility toward, the rest of the material world" (144). When considered seriously and experienced firsthand, these works allow us to refigure the relationship between ourselves and the world into a holistic, encapsulated view.

Christina Yglesias is an artist, educator, and writer who studies feminist post-cinema, focusing on bridging the gaps between new media, expanded cinema, feminist film theory, and the history of feminist video art. She teaches video, photo, and new media classes and workshops to adults and youth at universities, community arts organizations, and nonprofits. 